\title{
Relacje polsko-ukraińskie jako czynnik warunkujący tożsamość Iwowian
}

Wielowiekowe relacje między Polakami i Ukraińcami w Galicji odegrały ważną rolę w kształtowaniu się tożsamości narodowej mieszkańców regionu. Jednakże na przeszkodzie do wytworzenia spójnej wspólnej tożsamości regionalnej stanęły bardzo podobne w swojej naturze, choć wewnętrznie sprzeczne, roszczenia do tego samego terytorium. Tym niemniej, pomimo skomplikowanych okoliczności historycznych, jedną wspólną cechę lwowianie zachowali - mianowicie swoją europejskość.

Próbując opisać typowego mieszkańca Lwowa, Andrij Bondar przedstawił następującą opinię: „Lwowiak - to przede wszystkim osoba kulturalna i zawsze przyjmuje zasługi swego miasta $\mathrm{z}$ wielką dumą. Lwowiak uważa, że dobrze zna język polski, ale od jego wschodniego akcentu więdną uszy nawet u przemyślan"1. Nie zaskakuje, że element polski jest obecny w tej charakterystyce, jako że długotrwałe współistnienie Ukraińców i Polaków na jednym terytorium nie mogło nie zostać odzwierciedlone w strukturach umysłowych społeczności, która na nim żyje. Jak zauważył Manuel Castells, lokalne tożsamości krzyżują się z innymi źródłami znaczeń ${ }^{2}$. Ich związek i wpływ wzajemny jest unikalny dla każdej wspólnoty terytorialnej. We wstępie do swojego artykułu Lwowska identyczność: knajpy - kalafiory - stienky O. Krywdyk zauważył, że: „Tożsamość - to

\footnotetext{
* Postgraduate researcher, I. F. Kuras Institute of Political and Ethno-National Studies, National University of Kyiv-Mohyla Academy.

1 A. Bondar, Ne mij L'vìv, L'vìv 2008, s. 384.

2 M. Castells, The Information Age: Economy, Society, and Culture, Oxford 2004, s. 64.
} 
jest góra lodowa. Mimo że nadchodzi globalne ocieplenie, które może rozpuścić ją jako taką, to byłoby warto zobaczyć jej podwodną częśćn" . Parafrazując, określenie to $\mathrm{w}$ odniesieniu do tożsamości uwypukla niedostrzegalny aspekt tworzenia się tożsamości regionalnej, zatem to, co nieuchwytne dla ludzkiego oka, przybiera postać podwodnej, ukrytej części Lwowa. Ta podwodna część Lwowa ewoluowała przez wieki i znalazła się pod wpływem bogatego zestawu czynników, wśród których wcale nie ostatnie miejsce zajmowały i nadal zajmują stosunki polsko-ukraińskie.

Miasto Lwa zostało założone w połowie XIII wieku. Istotnym czynnikiem umocnienia na przestrzeni wieków jego pozycji było przede wszystkim dogodne położenie na skrzyżowaniu głównych szlaków handlowych między Wschodem i Zachodem, a więc na styku dwóch cywilizacji: łacińskiej i bizantyjskiej. Taka cecha miasta odegrała niejednoznaczną rolę w jego historii. W swojej pracy Potrójny Lwów czyli Kronika miasta Lwowa Bartłomiej Zimorowicz nazywa to miasto trójgrodem. Według informacji przekazanych przez historyka, istniały trzy miasta ${ }^{4}$. Pierwsze, założone przez Lwa, było ruskie, nazywano je Lwigrodem, drugie - Lemberg - pierwotnie było niemieckie, a później, od 1551 roku, stało się polskie. Według kronikarza Dionizego Zubryckiego, Polacy przejęli zarządzanie miastem od Niemców trochę wcześniej, po roku 1517, ponieważ właśnie wtedy po raz ostatni akta miejskie były spisane w języku niemieckim 5 . Mimo to, Niemcy nadal zajmowali czołowe miejsce w społeczności miejskiej, ale według tego samego historyka, „stałe było wymieszanie obu narodów między sobą, jak również poprzez wspólne obowiązki społeczne, tak że dla Polaków otworzyła się droga i podejście do rady"6. W ten sposób polska grupa etniczna stała się dominująca w regionie, podczas gdy Rusinom pozostała rola znajdującej się w gorszym położeniu mniejszości. Natomiast ludność żydowska miasta przyczyniła się do wzmocnienia pozycji zajmowanej przez Polaków. Ponadto, według Stanisława Vincenza, „Żydzi w żadnym innym mieście nie przyczynili się tak wyraziście do wzmocnienia wszystkiego, co polskie, tak jak we Lwowie" . W znacznej mierze pomoc ta wynikała z postawy, jaką prezentowali Żydzi. Nie wnosili oni żadnych pretensji do przywództwa, w przeciwieństwie do Polaków oraz Rusinów. Neutralność Żydów w konfliktach etnicznych, a także podczas ataków na Lwów, spowodowała negatywną reakcję wśród Ukraińców. Trzeba zauważyć, że „w latach 1920-1921 Żydzi

\footnotetext{
3 O. Krivdik, L'vivs'ka identičnist': knajpi - kalâfjori - stênki, L’vìv 2008, s. 28.

4 B. Zìmorovič, Potrijnij L'viv tob to Hronika mista L'vova, „Nezaležni kul'turologičnij časopis «Ï»", http://www.ji.lviv.ua/n29texts/zimorowicz.htm [dostęp: 2.03.2006].

5 İ. Lemko, Cikavinki z istoriï L'vova, L’vìv 2011, s. 23-24.

6 Ibidem, s. 1-44.

7 S. Vìncenz, Židivs'kì temi. Uâvna dijstnist', L'vìv 2009, s. 76-77.
} 
galicyjscy masowo bronili Polski, pomimo irytujących antysemickich ekscesów we Lwowie końca 1918 roku. Krótko mówiąc, Austria była dla nich kontynuacją Polski, a nowa Polska wydawała się im kontynuacją Austrii”". Wymuszone, wielowiekowe współistnienie i współdziałanie z Polakami miało bezpośredni wpływ na umysłowe wyobrażenia Rusinów, a później i Ukraińców. Badając początki lwowskiej europejskości, Ilko Łemko następująco podsumował rolę polskiego czynnika: „Europejczykami Galicjanie stali się z powodu aneksji przez Rzeczpospolitą, zostali wciągnięci do »raju europejskiego « faktycznie przymusowo, za uszy. Jakkolwiek by było, stali się przecież Europejczykami i ta europejskość stała się kamieniem narożnym naszej mentalności galicyjskiej aż do dnia dzisiejszego"9. I jest to całkiem zrozumiałe, zważywszy, że Lwów jest położony bliżej Warszawy i Krakowa niż stolicy Ukrainy. Mieszkańcom Lwowa zatem bliżej do Wiednia niż Odessy, bliżej do Drezna niż Dniepropietrowska, bliżej do Wenecji niż Ługańska ${ }^{10}$. Jednak lwowiacy zawdzięczają Polakom nie tylko swoją europejskość, ale przede wszystkim początki tworzenia narodowej „ukraińskiej” tożsamości. Wspólna przynależność terytorialna przez całe wieki powodowała napięcia w stosunkach między Polakami i Ukraińcami. Rzutował na to fakt, że oba narody rozpatrywały ten sam obszar jako arenę do realizacji własnych aspiracji politycznych. I właśnie problem rozdzielenia Galicji był stałym katalizatorem konfliktu na tle etnicznym. Iwan Monolatij przedstawił wzajemne uprzedzenia ukraińsko-polskie, a nawet nienawiść, używając słów Leopolda von Sacher-Masocha, który z kolei cytował dwa przysłowia. Pierwsze, polskie: „Jak długo będzie istniał świat, Polak nie był i nie będzie Rusinowi brat” i drugie ukraińskie: „Co Lach, to wróg”"11. Jednakże konfrontacja między dwoma narodami nie od razu nabrała charakteru politycznego, do połowy XIX wieku była ona w dużej mierze apolityczna, ponieważ okres polityki masowej rozpoczął się dopiero od 1848 roku $^{12}$.

Pojawiające się konflikty rozwiązywano na płaszczyźnie prawnej. Myron Kapral zbadał konfrontację prawną między Polakami i Rusinami w swojej książce Wspólnoty narodowe Lwowa XVI-XVIII wieku. Według tego autora, ruska wspólnota aktywizowała się w XV wieku. Impulsem do tego była decyzja Rady Miasta Lwowa z roku 1525. Wówczas rada miasta nie dała Rusinom uprawnień do swobodnego prowadzenia handlu i działalności rzemieślniczej, a także dołączenia do gildii, kupowania nieruchomości w którejkolwiek części

\footnotetext{
8 Ibidem.

9 İ. Lemko, L'vivi êvropejs'kist', L'vìv 2013, s. 5.

10 Ibidem.

11 İ. Monolatij, „Svoï”/„čužì” identičnost, „Nezaležnij kul'turologičnij časopis «Ï»”, http:// www.ji.lviv.ua/n58texts/monolatij.htm, s. 20 [dostęp: 3.05.2016].

12 V. Rasevič, Leopolis, L’vìv 2008, s. 48.
} 
śródmieścia ${ }^{13}$. W tamtych czasach tego rodzaju spory były rozstrzygane w drodze postępowania sądowego. W pierwszej połowie XVI wieku społeczność ruska $\mathrm{w}$ dalszym ciągu zmagała się z ograniczeniami religijnymi i gospodarczymi. Na skutek tego, w dniu 20 maja 1571 roku król Zygmunt August w swoim przywileju zrównał uprawnienia społeczności ukraińskiej i katolickiej we wszystkich strefach życia religijnego, gospodarczego, prawnego i kulturowe$\mathrm{go}^{14}$. Jednak to rozwiązanie nie tylko było ignorowane, ale także zostało odwołane w dniu 21 czerwca 1578 roku przez króla Stefana Batorego ${ }^{15}$. Pomimo ciągłego prześladowania społeczności ukraińskiej, konfrontacje z Polakami miały zwykle charakter pokojowy, z wyjątkiem niektórych epizodów. Jak zaznaczał M. Kapral, „,konflikty z elementami przemocy eksplodowały zazwyczaj w krótkich okresach wprowadzenia kalendarza gregoriańskiego, kontrowersji wokół zawarcia unii czy wojny wyzwoleńczej z połowy XVII wieku"16. Po tym konfrontacja ponownie wracała do ram prawnych. Jednak z czasem stała się ona czynnikiem zbiorowej identyfikacji. Przecież Rusini byli nie tylko mniejszością, która cierpiała ucisk ze strony uprzywilejowanej polskiej społeczności i nie miała dostępu do władz miasta, odróżniali się także swoimi elementami kulturowymi i religijnymi. Tak więc, długotrwała styczność, a nawet konfrontacja w wymiarach prawnym, ekonomicznym, a zwłaszcza religijnym sprzyjała „przyciąganiu szerszego grona ludności ukraińskiej do sprawy narodowej, przejawom świadomości narodowej wśród wiodącej warstwy ukraińskiej społeczności Lwowa, która grupowała się wokół bractwa Stauropigijskiego"17.

Proces kształtowania się tożsamości lwowian determinowany był głównie przez wielorakość czynników zewnętrznych, wśród których wyróżniał się olbrzymi wpływ kultury łacińskiej, z jaką byli związani mieszkańcy Lwowa poprzez historyczną przynależność do I i II Rzeczypospolitej, tym samym nieprzerwanie orbitując $\mathrm{w}$ kręgu kultury europejskiej. Z rzadka dostrzegalne było oddziaływanie kultury bizantyjskiej, objawiając się sporadycznie poprzez epizodycznie przybywających mieszkańców z wschodnich rubieży ziem ukrainnych. Nie można pominąć także czynników wewnętrznych, w tym długotrwałego współistnienia z Polakami, co w rezultacie zaowocowało tworzeniem się rozbudowanej świadomości narodowej i konsolidacją mniejszości ukraińskiej.

Lwów należał do Rzeczypospolitej w latach 1387-1772, następnie przeszedł do Austrii, a potem - do Austro-Węgier. W tym okresie miasto, które było

13 M. Kapral, Nacional'ni gromadi L'vova XVI-XVIII st., L'vìv 2003, s. 98-99.

14 Ibidem, s. 102.

15 Ibidem, s. 104.

16 Ibidem, s. 155.

17 Ibidem, s. 157. 
centrum Królestwa Galicji i Lodomerii aktywnie realizowało swój potencjał, wynikający ze statusu stolicy kulturalnej. W 1918 roku doszło do wydarzenia znaczącego dla ruchu wyzwolenia narodowego. W dniu 13 listopada Lwów został ogłoszony stolicą Zachodnioukraińskiej Republiki Narodowej. Jednak chwila triumfu nie trwała długo i miasto wróciło pod władzę Rzeczypospolitej. Na przegraną strony ukraińskiej istotny wpływ miało małe rozeznanie w infrastrukturze miasta. O tym mówi też I. Łemko: „Ukraińcy zostali pokonani $w$ walkach listopadowych, bo nie znali dobrze miasta i nie orientowali się w nim, w przeciwieństwie do rdzennych lwowiaków-orlą" ${ }^{18}$. W okresie międzywojennym mapa narodowościowa przedmieść Lwowa kształtowała się w sposób następujący: Hołosko wielkie i Krywczyce - Rusinów jedna trzecia, reszta - Polacy; Riasna Ruska - przeważnie Rusini; Riasna Polska - głównie Polacy; Sichów - Rusinów jedna trzecia, reszta - Polacy; Kozielniki - głównie Polacy; Skniłów - głównie Rusini; Skniłówek i Zboiska - jednakowo Polaków i Rusinów ${ }^{19}$. Polski okres w historii Lwowa zakończył się w 1939 roku, kiedy miasto zostało włączone do ZSRR. Jednocześnie stolica Galicji straciła takie charakterystyczne dla niej cechy, jak wielonarodowość i wielokulturowość. Jak zauważyła Iryna Magdysz, „po masakrze II wojny światowej poszły w zapomnienie całe lwowskie światy - żydowski, niemiecki, austriacki, polski. Natomiast powstał Lwów monosowiecki”" ${ }^{20}$. W związku z powyższym zamknął się jeden z kluczowych etapów rozwoju tożsamości regionalnej lwowian, obfitujący w bogate doświadczenia społeczne, z których wytworzyła się własna odrębność i niepowtarzalność kulturowa oraz świadomość historycznego trwania i ciągłości zbiorowości ukraińskiej.

Sytuacja zmieniła się w wyniku znaczących zmian demograficznych społeczności miejskiej, spowodowanych przez II wojnę światową i powojenne wydarzenia. Z ludności rdzennej pozostała tylko niewielka część. We wspólnej pracy Lwów codzienny autorzy, W. Mihalik i I. Łemko, podkreślają, że Lwów sowiecki najboleśniej odczuł skutki tragicznego podziału Europy i drastycznych zmian demograficznych, właściwych dla całego ZSSR ${ }^{21}$. Polacy masowo wyjeżdżali lub ich deportowano. Dla porównania, w czasie II wojny światowej było ich $63 \%$, a w 1989 roku - tylko 1,2\% ${ }^{22}$. W ramach planu budowy sowieckiego Lwowa do miasta przenieśli się Rosjanie i rosyjskojęzyczni Ukraińcy ze Wschodu, których zadaniem było wypełnienie próżni po Polakach i Żydach.

\footnotetext{
18 V. Mihalik, İ. Lemko, L'vìv povsâkdennij, L'vìv 2009, s. 6.

19 Ibidem, s. 82.

20 İ. Magdiš, Mono - malo - kul'turnij L'viv, „Bagato kul'turnij L’vì”, http://ji.lviv.ua/ n58texts/N58-lviv.htm [dostęp: 2.10.2016].

21 V. Mihalik, İ. Lemko, op. cit., s 6.

22 Ibidem.
} 
Jak twierdzi W. Rasewicz, ogółem w czasach powojennych do Ukrainy Zachodniej zostało przesiedlonych ponad milion Rosjan i wschodnich Ukraińców ${ }^{23}$. Proces ten miał sprzyjać głównie rusyfikacji Galicji, która była postrzegana przez władze centralne jako wrogo nastawiona ze względu na jej rolę w walce narodowowyzwoleńczej. Negatywne postawy wobec regionu doprowadziły do tego, że, jak podaje W. Rasewicz, słowo "galicyjski« stało się przekleństwem i przeszkodą dla możliwości rozwoju zawodowego"24. Procesu odgórnej rusyfikacji nigdy nie zrealizowano pomyślnie, ponieważ zakładany efekt został zniwelowany przez gwałtowny napływ ludności wiejskiej pochodzenia ukraińskiego. Przyczyniło się do tego oddziaływanie miasta jako prężnego i atrakcyjnego ośrodka przemysłowego, ponadto życie we Lwowie było alternatywą dla biednego mieszkańca wsi. W wyniku tego, w 1989 roku odsetek Ukraińców wynosił $80 \%$, a w 2001 roku wzrósł do 88,1\%. W tym czasie mieszkało we Lwowie 8,9\% Rosjan, 0,4\% Białorusinów, 0,1\% Ormian, 0,3\% Żydów i 0,9\% Polaków $^{25}$. Dane spisowe potwierdzają tezę I. Łemki, że „po II wojnie światowej kamienie pozostały - ludzie znikli”26. Jednak pamięć zbiorowa stała się kluczem do zachowania mapy mentalnej lwowian. Kulminacją walki narodowowyzwoleńczej stało się ogłoszenie Deklaracji Niepodległości Ukrainy. W referendum narodowym 1 grudnia 1991 roku na pytanie: „Czy popieracie Deklarację Niepodległości Ukrainy?” odpowiedź twierdzącą dało 90,32\% ludności kraju, podczas gdy w obwodzie lwowskim - 97,46\% ${ }^{27}$. Samookreślenie ukraińskiego etnosu, deklaracja niepodległości oznaczały również konieczność określenia swojego miejsca w stosunkach międzynarodowych. Dla Galicji Warszawa nadal pozostawała ważnym punktem orientacyjnym w nowym układzie współrzędnych na mocy osobliwości historycznych, kulturowych i geograficznych. W pierwszej dekadzie istnienia niepodległego państwa ukraińskiego stosunki ukraińsko-polskie przeszły długotrwałą transformację, na przebieg której rzutowało wiele trudnych kwestii. Najbardziej ostrymi pozostawały przez długi czas tragedia wołyńska i Cmentarz Orląt. Lwów otrzymał rolę symbolicznego miasta pojednania między Polakami i Ukraińcami. Misja ta została uzasadniona przez miejsce, które zajmowało miasto w historii obu narodów. Pomimo faktu, że Lwów, jak zauważył M. Riabczuk, nigdy nie odegrał kluczowej roli w żadnym z państw, do których należał, „ani tym bardziej nie był rzeczywiście

\footnotetext{
${ }^{23}$ V. Rasevič, op. cit., s. 112.

24 Ibidem.

25 Pro kil'kist' ta skladnaselennâ L'vivs'koï oblastì zapidsumkami Vseukraïns'kogo perepisu naselennâ $2001 \mathrm{roku}$, http://2001.ukrcensus.gov.ua/results/general/nationality/lviv/ [dostęp: 11.09.2016].

26 İ. Lemko, L'viv i êvropejs'kìst', L'vìv 2013, s. 8.

27 İ. Kotlobulatova, Dati i podiï v istoriï L'vova, L’vìv 2009, s. 200.
} 
ważnym politycznym, kulturalnym i gospodarczym »centrum «na europejskiej lub światowej mapie", to odegrał on ważną rolę tak dla Polaków, jak i dla Ukraińców, ponieważ był centrum ,jedynego terytorium, gdzie Polacy i Ukraińcy mogli jakoś pielęgnować swój język, kulturę i tożsamośćn" ${ }^{28}$. Dla Ukraińców Lwów stał się Piemontem, po tym jak wcześniej był nim dla Polaków. Kolejny krok stanowiła symboliczna transformacja Galicji w Ukrainę Zachodnią. Właśnie o takiej ewolucji mówił A. Zajcew w artykule Lwów nacjonalistyczny: mit czy rzeczywistość?. Według autora, pozytywny mit Lwowa jako twierdzy ukraińskiego ducha wytworzył się w kontrze do mitu polskiego miasta Semper Fidelis - czyli zawsze wiernego Rzeczypospolitej29. Początkowo stało się ono miastem wiernym Ukrainie, a później - „otwartym na świat”. Właśnie to przesłanie, posiadające głębokie historyczne konotacje, wytyczyło nowy kurs dla Lwowa w latach 90. XX wieku już w niepodległej Ukrainie. Wówczas oficjalne stosunki między krajami od momentu ich ustalenia były przyjazne i zmierzały w kierunku strategicznego partnerstwa między oboma państwami. Znaczącym krokiem w kierunku porozumienia międzynarodowego było spotkanie prezydentów obu państw we Lwowie, w czerwcu 2005 roku. Wówczas udało się rozwiązać problem Cmentarza Orląt. Podczas uroczystości odsłonięte zostały pomniki francuskich piechurów i amerykańskich lotników. Władze we Lwowie nie zgodziły się jedynie na rekonstrukcję kamiennych lwów i szczerbca, ponieważ radni uznawali je za symbole polskiej ekspansji. Symboliczne znaczenie otwarcia Cmentarza Orląt dobrze zilustrował prezydent Aleksander Kwaśniewski: „Otwarcie Cmentarza Orląt Lwowskich jest spełnieniem potrzeby polskich serc oraz znakiem pokoju, pojednania i przyjaźni płynącym z serc ukraińskich. Potrafimy to docenić. W imieniu Polski i Polaków mówię ze wzruszeniem w tym wielkim, historycznym dniu: Dziękujemy!"”30. Tego samego dnia, 24 czerwca odbyła się ponadto uroczystość przy Memoriale Żołnierzy Ukraińskiej Armii Galicyjskiej, w której udział wzięli m.in. prezydenci Polski i Ukrainy.

Należy jednak zauważyć, że porozumienie to nie zostało osiągnięte na wszystkich poziomach. Nadal tragedia wołyńska pozostaje bolesnym tematem dla historyków po obu stronach Bugu. Gazeta „Dzień” w dniu 5 marca 2013 roku opublikowała artykuł Dwa wymiary stosunków polsko-ukraińskich, którego autorem był Henryk Litwin. Ambasador Polski na Ukrainie dokonał w nim przeglądu stosunków międzypaństwowych na przestrzeni 20 lat od

28 M. Râbčuk, İstorična ì politična marg̀inalizaciâ L’vova, L'vìv 2008, s. 64.

29 O. Zajcev, L'viv nacionalističnij: mif či real'nist, L’vìv 2008, s. 160.

30 T.A. Tupalski, Stosunki polsko-ukraińskie w latach 2004-2010, „Colloquium Wydziału Nauk Humanistycznych i Społecznych" 2014, nr 3, s. 141. 
chwili podpisania polsko-ukraińskiego Traktatu o przyjaźni i dobrych stosunkach sąsiedzkich. Według autora, „ten dokument jest efektem polityki, którą Polska rozpoczęła w 1989 roku, zaraz po otrzymaniu pełnej niepodległości”31. Potwierdzeniem tych słów jest fakt, że Polska, wyprzedzając Kanadę, pierwsza przekazała stronie ukraińskiej dokumenty formalne o uznaniu jej niepodległości i chęci nawiązania stosunków dyplomatycznych. Według H. Litwina, stało się to

symbolicznym i ostatecznym sukcesem, który nie był tak ważny dla żadnego innego kraju niż Polska. Polacy i Ukraińcy, którzy mieszkali w pobliżu granicy, zaczaili się we wzajemnej wrogości po inwazji na ich terytorium i bratobójczej walce z Armią Czerwoną, a sowiecka dominacja dążyła do unieruchomienia rozwoju stosunków między dwoma narodami przez długie dziesięciolecia ${ }^{32}$.

Jednak nowy kurs polskiego MSZ, polegający na pragnieniu, by ,jednocześnie mieć dobre stosunki z Rosją i wspierać dążenia do niepodległości republik ZSRR, a po roku 1991 - ściśle współpracować z nowo utworzonymi państwami i posiadać uregulowane stosunki dwustronne", nie przyczynił się do złagodzenia napięć między oboma państwami. Według samego ambasadora, który rozpoczął pracę jako szef Agencji Konsularnej we Lwowie w czerwcu 1991 roku, „na początku lat 90. w zachodniej Ukrainie w kręgach działaczy politycznych dominowała wrogość i brak zaufania do Polaków"33. Nieufność między Polakami i Ukraińcami była przekazywana z pokolenia na pokolenie, dlatego zmienić formułę ze „swój” - „wrogi, obcy” na coś innego było niezwykle trudno.

Dodatkowo do podsycania tego rodzaju postaw przyczyniała się prasa i incydentalne prowokacje, potwierdzają to chociażby materiały gazety „Visokij zamok" m.in. w numerze z dnia 5 sierpnia 1995 roku został opublikowany materiał o pomniku postawionym w Lublinie. Według tego artykułu, pomnik przedstawiał lwowskiego lwa z tarczą, polską wersją herbu miasta i napisem Semper Fidelis, z celowym zignorowaniem współczesnego oficjalnego godła miasta ${ }^{34}$. W artykule Każdy ma swój ból z dnia 7 grudnia został ogłoszony protest Centrum Informacji Lwowskiego Komitetu Wykonawczego przeciw instalacji na polskim cmentarzu wojskowym tabliczek $\mathrm{z}$,jednostronnym obciążeniem ideologicznym”, takich jak „nieznanym bohaterom, którzy polegli w obronie miasta i kresów południowo-wschodnich". W kolejnych artykułach tego czasopisma pojawiają się bardzo surowe sformułowania: „nikt inny, tylko polscy militaryści pod pozorem pomocy Polakom ze Lwowa rozpoczęli przeciw nowo utworzonej

31 G. Lìtvìn, Dva vimiri pol's'ko-ukraïns'kih vidnosin „,Den”, http://www.day.kiev.ua/uk/ article/svitovi-diskusiyi/dva-vimiri-polsko-ukrayinskih-vidnosin [dostęp: 4.09.2016].

32 Ibidem.

33 Ibidem.

34 V. Lâškìvs'kij, Lûbov do L'vova po-lûblins'ki, „Visokij zamok” 1995, nr 95, s. 3. 
1 listopada 1918 roku Zachodnioukraińskiej Narodowej Republiki krwawą wojnę, która przyczyniła się do tysięcy ofiar i okupacji ziem zachodniej Ukrainy"35. I dalej: „Lwowa i całej ziemi Galicji w latach 1918/19 broniła od polskich najeźdźców Ukraińska Galicyjska Armia. I to powinni w końcu uświadomić sobie wszyscy"36.W dniu 12 listopada 1996 roku ukazał się artykuł w rubryce pod tytułem Ukrainofobia po polsku. Odnosił się on do sprawy pozwu przeciwko Mikołajowi Sywickiemu, autorowi trzytomowej Historii konfliktów polsko-ukraińskich, który został oskarżony o nawoływanie do separacji południowo-wschodnich ziem polskich, co było naruszeniem integralności terytorialnej państwa ${ }^{37}$. Od 1997 roku Polska stała się regularnym adresatem rubryki Nie po sąsiedzku, w której jednak w dniu 15 kwietnia w artykule Przepraszamy i prosimy o przebaczenie została opublikowana informacja na temat akcji „Wisła”, z przypomnieniem, że z okazji 50. rocznicy tego wydarzenia odbył się w Warszawie Kongres Ukraińców Pol$\mathrm{ski}^{38}$. W tym samym roku, na skutek napięcia we wzajemnych stosunkach między oboma państwami, pod znakiem zapytania stała kwestia organizacji Festiwalu Kultury Ukraińskiej w Przemyślu. Ponadto nerwową atmosferę spotęgowała informacja ze strony polskiej z dnia 26 czerwca. Wówczas opublikowany został komunikat związany z Przemyślem, gdzie w wojskowym kościele garnizonowym znaleziono pamiątkową tablicę $\mathrm{z}$ tryzubem odwróconym i następującym tekstem: „Niewinnej ludności polskiej, bestialsko mordowanej przez bandy UPA na kresach południowo-wschodnich Rzeczypospolitej w latach 1942/48"39. Oczywiście, nie obeszło się i bez prowokacji także po stronie ukraińskiej. W rocznicę uchwalenia konstytucji wyróżnili się w tych działaniach przedstawiciele UNSO, którzy rzucili u podnóża pomnika Tarasa Szewczenki flagi Polski, Rosji i Rumunii, następnie je podeptali, a potem rozerwali ${ }^{40}$. Stosunek obu narodów do wspólnej historii jest pełen emocji, o czym świadczą odmienne optyki, a także zróżnicowana narracja o przeszłości. Dla strony polskiej tragedia wołyńska w latach 1943-1944 to problem ludobójstwa, natomiast strona ukraińska prezentuje postawę zakładającą, że na ziemiach zachodniej Ukrainy w latach 40. XX wieku miał miejsce konflikt polsko-ukraiński, a ofiary były po obu stronach.

$\mathrm{Z}$ początkiem nowego tysiąclecia w relacjach między Polską a Ukrainą dostrzec można było pozytywne przemiany, do których przyczyniły się zasadniczo wydarzenia z 2004 roku: przystąpienie Polski do UE, a także pomarańczowa rewolucja. Bezpośrednie sąsiedztwo granicy z Unią Europejską, a także

\footnotetext{
35 U kožnogo svij bil', „Visokij zamok” 1995, nr 166, s. 2.

36 Ukraïnofobiâ po-pol's'ki, „Visokij zamok” 1996, nr 172, s. 2.

37 M. Levic'kij, Vibačaêmo i prosim o vibačennâ, „Visokij zamok” 1997, nr 59, s. 1-5.

38 Ibidem.

39 Divna tablicâ; pol's'komu vijs'kovomu kosteli, „Visokij zamok” 1996, nr 101, s. 3.

40 Čim zavinili prapori?, „Visokij zamok” 1997, nr 103-104, s. 1.
} 
aspiracje Ukrainy, by stać się członkiem stowarzyszonym organizacji, ponadto rola Polski w promowaniu interesów swego sąsiada, odegrały w tej przemianie swoją rolę. Później czynnikiem zbliżającym oba narody stało się Euro 2012. Według wyników badania przeprowadzonego przez socjologiczną grupę Rejting, 45\% Ukraińców było pozytywnie nastawionych wobec polskiego prezydenta Bronisława Komorowskiego, a około 90\% miało pozytywne nastawienie do Europejczyków, Polaków, Litwinów i Niemców ${ }^{41}$. W tym samym czasie, według materiałów polskiego Centrum Badania Opinii Społecznej, z badania przeprowadzonego na początku stycznia 2013 roku wynika, że liczba Polaków z pozytywnym nastawieniem wobec Ukrainy w ciągu 20 lat wzrosła z 13\% do 31\%, zaś liczba negatywnie nastawionych zmniejszyła się o połowę - z 65\% do $33 \%{ }^{42}$.

Reasumując, proces kształtowania się tożsamości narodowej mieszkańców Galicji, bazującej na wielowiekowych zawiłych relacjach między Polakami i Ukraińcami, utrudniał identyfikację lwowian. Lwów, stanowiący centrum Galicji, która nie bez powodu była uznawana za „Dziki Zachód” imperium Habsburgów, przejął na siebie rolę mitycznego Babilonu, gdzie wymieszane były narody, języki, tradycje, obyczaje i religie. Historycznie złożyło się tak, że element ukraiński długo pozostawał w mniejszości w regionie, ustępując ilościowo i jakościowo najpierw Niemcom, Żydom, Rosjanom, a następnie Polakom. Interakcje z tymi ostatnimi były i pozostają ważnym czynnikiem tworzenia się tożsamości lwowiaków. Polacy dominowali we Lwowie do 1945 roku. Jednakże przez ten cały okres współistnienia dwóch narodów i tak nie została stworzona silna wspólna tożsamość regionalna. Przyczyn było kilka. Przede wszystkim Polaków i Ukraińców dzieliły język, kultura i religia, a także, co nie mniej ważne, przeciwne narodowe idee o „prawdziwej polskiej Galicji i o najbardziej ukraińskiej Ukrainie" ${ }^{43}$. W opozycji do dominującej polskiej społeczności na bazie schematu „swój - obcy” narodziła się ukraińska narodowa irredenta. Obywatele Lwowa zawdzięczają Polakom to, co dla nich najcenniejsze i co stanowi swoistą cechą charakterystyczną miasta, z której zawsze byli dumni - europejskość. Wewnętrzna świadomość siebie jako części Europy, spowodowana przez połączenie czynników historycznych i geograficznych, bliskość granicy z Unią Europejską, określiły wybór orientacji mieszkańców regionu w międzynarodowym układzie współrzędnych. Po ogłoszeniu niepodległości Ukrainy między państwami zostały nawiązane przyjazne stosunki. Natomiast nierozwiązane, historycznie odziedziczone problemy przez długi czas pozostawały przeszkodą w przyjaznych stosunkach międzypaństwowych. Po przystąpieniu do

${ }^{41}$ Seredino zemnih lideriv, najbil'še lûblât' - opituvannâ, „Ukraïns'ka Pravda”, http://www. pravda.com.ua/news/2014/09/23/7038653/ [dostęp: 23.09.2014].

42 Stavlennâ polâkiv do ukrä̈nciv, http://tvi.ua/new/2013/02/03/stavlennya_polyakiv_do_ ukrayinciv_zminylos_za_20_rokiv_-_opytuvannya [dostęp: 3.02.2013].

43 V. Rasevič, İstoriâ mìfu Galičini, L’vìv 2008, s. 106. 
UE Polska występuje w roli adwokata Ukrainy, regularnie broniąc jej interesów. To, a także pomarańczowa rewolucja, Euro 2012 i „rewolucja godności” przyczyniły się do zbliżenia między obu narodami. Lecz pomimo tych pozytywnych poczynań we wzajemnych oficjalnych stosunkach, na tożsamość lwowian coraz częściej wpływa postawa zdecydowanej części elit intelektualnych współczesnego Lwowa, mitologizująca wyobrażenie o wielokulturowości tego miasta i jego przynależności „od zawsze” do Europy, z dominującym językiem ukraińskim, przy jednoczesnej marginalizacji tysiącletniej przynależności do państwa polskiego, co w efekcie kształtuje zafałszowany obraz miasta i jego mieszkańców.

\section{Bibliografia}

Bondar A., Ne mij L'viv, L'vì 2008.

Castells M. The Information Age: Economy, Society, and Culture, vol. 2: The Power of Identity, Oxford 2004.

Čim zavinili prapori?, „Visokij zamok” 1997, nr 103-104.

Divna tablicâ;; pol's'komu vijs'kovomu kosteli, „Visokij zamok” 1996, nr 101.

Kapral M., Nacional'ni gromadi L'vova XVI-XVIII st., L'vìv 2003.

Kotlobulatova İ., Dati i podii v istorii L'vova, L'vìv 2009.

Krivdik O., L'vivs'ka identičnist': knajpi - kalâfjori - stênki, L'vìv 2008.

Lâškìs'kij V., Lûbov do L'vova po-lûblins'ki, „Visokij zamok” 1995, nr 95.

Lemko İ., Cikavinki z istorii L'vova, L'vìv 2011.

Lemko İ., L'viv i êvropejs'kist', L'viv 2013.

Levic'kij M., Vibačaêmo i prosim o vibačennâ, „Visokij zamok” 1997, nr 59.

Litvìn G., Dva vimiri pol's'ko-ukraïns'kih vidnosin, „Den”, http://www.day.kiev. ua/uk/article/svitovi-diskusiyi/dva-vimiri-polsko-ukrayinskih-vidnosin [dostęp: 4.09.2016].

Magdiš İ., Mono- malo-kul'turnij L'viv, „Bagato kul'turnij L'vìv”, http://ji.lviv.ua/ n58texts/N58-lviv.htm [dostęp: 2.10.2016].

Mihalik V., Lemko İ., L’viv povsâkdennij, L'vìv 2009.

Monolatij İ., „Svoï”/ „čuži” identičnostì, „Nezaležnij kul'turologičnij časopis «Ï»", http://www.ji.lviv.ua/n58texts/monolatij.htm [dostęp: 3.05.2016].

Prokil'kist'ta skład naselennâ L'vivs'koï oblastì zapidsumkami Vseukraïns'kogo perepisu naselennâ 2001 roku, http://2001.ukrcensus.gov.ua/results/general/nationality/lviv/ [dostęp: 11.09.2016].

Râbčuk M., İstorična i politična marg̀inalizaciâ L’vova, L'vìv 2008.

Rasevič V., İstoriâ mifu Galičini, L’vì 2008.

Rasevič V., Leopolis, L’vì 2008. 
Seredino zemnih liderìv ukrä̈nci najbilšse lûblât' Lukašenka - opituvannâ, „Українська правда”, http://www.pravda.com.ua/news/2014/09/23/7038653/ [dostęp: 23.09.2014].

Stavlennâ polâkiv do ukraïnciv, ttp://tvi.ua/new/2013/02/03/stavlennya_polyakiv_ do_ukrayinciv_zminylos_za_20_rokiv_-_opytuvannya [dostęp: 3.02.2013].

U kožnogo svij bil', „Visokij zamok” 1995, nr 166.

Ukraïno fobiâpo-pol's'ki, „Visokij zamok” 1996, nr 172.

Vìncenz S., Židivs'kitemi. Uâvnadijsnist'?, L'vìv 2009.

Zajcev O., L 'viv nacionalističnij: mif či real'nist', L'vì 2008.

Zìmorovič B., Potrijnij L'viv tobto Hronika mista L'vova, „Nezaležnij kul'turologičnij časopis «ï»", http://www.ji.lviv.ua/n29texts/zimorowicz.htm [dostęp: 2.03.2006].

\begin{abstract}
The article addresses the problem of shaping the centuries-long relationship between Polish people and Ukrainians from Galicia, and discusses the factors influencing the process of shaping the national identity of the inhabitants of Lvov. The publication underlines the historical and ethnic backgrounds influencing the people living in Lvov region and in Lvov itself. The article also refers to the issue of identifying Lvov residents as Europeans. The author of the article also highlighted obstacles preventing the creation of solid foundation between the inhabitants of Lvov to build a common regional identity despite centuries of co-existence. The destabilizing elements were primarily claims to the same territory. Despite the complicated history, there is one common feature of the Lvov residents which has been preserved - as the author of the article points out - namely, their European identity. This belief has risen to the rank of myth. The article has made a synthetic analysis of the mutual relationship between Polish people and Ukrainians from the 15th century up to the present day, taking into account the influence of elements of collective memory. The current relations between the two nations are relatively well formed. After joining the EU, Poland acts as a Ukrainian supporter, regularly defending its interests. This, as well as the Orange Revolution, Euro 2012 and the Revolution of Dignity contributed to the untightened relations between these two nations. However, despite these positive actions in common relations, the attitude of a decisive part of the intellectual elite of modern Lvov residents is more and more influenced by the mythology of the multiculturalism of this city and its membership "ever since" to Europe, with the dominant Ukrainian language, and simultaneous marginalization of thousand years of belonging to the Polish state, which in effect creates a fake image of the city and its inhabitants.
\end{abstract}

Keywords: identification, regional identity, myth, collective memory, European identity 